\title{
Malay Local Wisdom Values in Elementary School Learning
}

\author{
Vany Sinthya ${ }^{1 *}$, Zaka Hadikusuma Ramadan ${ }^{2}$
}

1,2 Pendidikan Guru Sekolah Dasar, Universitas Islam Riau, Riau, Indonesia

\section{ART I CLE INF O}

Article history:

Received August 26, 2021

Revised August 28, 2021

Accepted September 30, 2021

Available online November 25, 2021

Kata Kunci:

Kearifan Local, Melayu,

Pembelajaran

Keywords:

Malay Local Wisdom, Learning

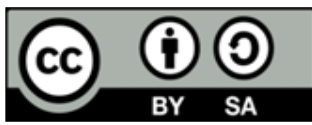

This is an open access article under the CC BY-SA license.

Copyright (C) 2021 by Author. Published by Universitas Pendidikan Ganesha.

\begin{abstract}
A B S T RAK
Pelaksanaan nilai kearifan lokal yang melibatkan guru dan siswa kurang berjalan dengan maksimal dikarenakan adanya dampak dari pandemic Covid-19. Hal ini menyebabkan pembelajaran tidak berjalan dengan optimal. Tujuan penelitian ini yaitu untuk menganalisis implementasi nilai-nilai kearifan lokal melayu dalam pembelajaran di sekolah dasar. Peneliti menggunakan pendekatan kualitatif dengan metode deskriptif. Subjek penelitian ini adalah 1 orang kepala sekolah, 7 orang guru dan 16 orang siswa. Peneliti melakukan observasi mulai dari kelas 1 sampai 6 dengan perwakilan berjumlah 6 kelas. Teknik pengumpulan data uang digunakan peneliti berupa wawancara, observasi, dokumentasi. Teknik analisis data yang digunakan adalah deskriptif kualitatif. Hasil penelitian menunjukkan bahwa nilai kearifan lokal melayu dilaksanakan dengan baik di sekolah dan pada setiap pembelajaran. Ada lima nilai kearifan lokal melayu yang diterapkan dalam pembelajaran yaitu nilai religius, nilai cinta damai, nilai gotong royong, nilai toleransi, dan nilai peduli lingkungan. Nilai kearifan lokal melayu ini sangat penting untuk diterapkan disekolah agar siswa memiliki moral, karakter, dan tata krama yang baik sehingga siswa bisa bersikap dan memiliki tingkah laku sesuai budaya yang ada dilingkungan mereka berada.
\end{abstract}

A B S T R A C T

The implementation of local wisdom values involving teachers and students is not running optimally due to the impact of the Covid-19 pandemic. It causes learning not to run optimally. This study aims to analyze the implementation of Sunda local wisdom values in learning in elementary schools. The researcher used a qualitative approach with a descriptive method. The subjects of this study were 1 principal, 7 teachers and 16 students. Researchers made observations starting from grades 1 to 6 with representatives of 6 classes. Data collection techniques used by researchers in interviews, observation, documentation. The data analysis technique used is descriptive qualitative. The results showed that the value of Sunda local wisdom was implemented well in schools and every lesson. Five discounts of local Sunda wisdom are applied in learning, namely religious values, peace-loving values, cooperation values, tolerance values, and environmental care values. The value of Malay local wisdom is significant to be applied in schools so that students have good morals, character, and manners to behave and behave according to the culture in their environment.

\section{INTRODUCTION}

Education is the process by which society, through educational institutions, intentionally transforms its cultural heritage, namely knowledge, values, and skills (Aragonés-González et al., 2020; Lyon, 2021; Maudsley \& Taylor, 2020). Education aims to form a cultured human character and create humans who have broad insights and intelligence (Nuryanti, 2019; Van Nuland et al., 2020). Education is not only a tool for transferring knowledge but also instilling an attitude of love for each other's culture (Amran et al., 2020; Faizah et al., 2019). With education, students can know their culture, love their culture and feel the culture itself. The culture referred to here is local culture or local wisdom that develops in the community (Hamdi et al., 2018; Marhayani, 2016). This local wisdom does not only develop in the community but also develops in the school environment and can be applied in learning (Alba et al., 2019; Nurafni et al., 2020). However, the current problem is that learning is still lacking in applying local wisdom in learning (Budiwibowo, 2016; Khoeriyah \& Mawardi, 2018). If local wisdom is combined in learning, it can shape the character of students (Alba et al., 2019; Sudarmiani, 2013; Wijaya et al., 2019). This problem was also found in one elementary school. Based on the results of observations conducted at SD Negeri 67 Pekanbaru, it was found that a problem, namely the implementation of local wisdom values involving teachers and students, did not run optimally due to the impact of the Covid-19 pandemic. Furthermore, from the observations, it 
was not seen that there were students who shook hands with the teacher when entering the school environment and when entering or leaving the classroom after learning was completed. Imtaq activities have also been cancelled to reduce the impact of the spread of COVID-19. Moreover, many other things that cannot be done because of this pandemic. It causes learning not to run optimally.

Local content is understood as a subject to support the area's potential where learning takes place (Aditya Dharma, 2019; Rachmadyanti, 2017). In elementary schools, local content learning is applied, namely Riau Malay Culture learning. Malay culture has been passed down from generation to generation by the Malay community (Tambak \& Sukenti, 2017; Wati, 2019). The Malay cultural tradition makes it part of the vision and mission of Riau Province to build a government in the Riau region. The government hopes that the Riau Malay community can preserve this Malay culture. Malay culture has received less response from some educational institutions. The potential of local wisdom can be used as a source of learning. Local wisdom is not only a local culture that develops in society but can also be used as a source of learning so that over time it can make new changes (Lestariningsih \& Suardiman, 2017; Sutarto, 2016). Several factors influence the formation of local wisdom, including geographical conditions, religious values, and community social conditions (Nurafni et al., 2020; Sutarto, 2016). The characteristics of local wisdom are: able to withstand foreign cultures; having the ability to accommodate foreign cultures; having the ability to integrate foreign cultures with indigenous cultures (Aryantini et al., 2018; Primayanti et al., 2019). With local wisdom, the community can maintain its developed culture so that when outside culture enters its territory, the community will not be affected and be able to control it (Khoeriyah \& Mawardi, 2018; Widyanti, 2015).

Local wisdom-based education teaches students to permanently be attached to the concrete situations they face (Daniah) (Aditya et al., 2019; Lidi et al., 2020). Local wisdom can direct individual behaviour in everyday life. So, local wisdom education is crucial because it can make students more aware of something tangible in their lives and make their behaviour more directed to avoid deviating from applicable norms and provisions (Khaerunnnisa \& Pamungkas, 2019; Rachmadyanti, 2017). Local wisdom in this study focuses more on the realm of values. Value is valuable, quality, and useful for humans (Barni et al., 2019; Brookhart et al., 2016). Through an assessment, we can measure something we see and observe somewhere. What we observe is positive or negative, and we can implement and apply it continuously or not (Aggari et al., 2020; Fauyan, 2019). The value of local wisdom concerns a person's moral values , shown through the language he displays when speaking. In addition to language speech, it can also be done by cultivating positive values that have become a habit from generation to generation (Aryantini et al., 2018; Primayanti et al., 2019). These values of life are then developed in the community and are known as local wisdom. The values of local wisdom of the Indonesian people, including religious values, cooperation values, environmental care values, peace-loving values, and tolerance values (Khoeriyah \& Mawardi, 2018; Widyanti, 2015). Religious values make a person have good morals and faith according to the teachings of his religion so that he will practice what God has ordered (DiMaggio et al., 2018; Saputro, 2020). The value of tolerance must exist in every human being because of having a sense of tolerance. Humans can respect and respect a group of people or communities both around their residence and outside their place of residence (Berggren \& Nilsson, 2016; Juarascio et al., 2016). It is no less important than the value of gotong royong. The value of gotong royong is instrumental in human life. By working together, something targeted by humans and the work that humans do can be completed quickly (Sujatmiko et al., 2019; Utomo, 2018). We also need to know the value of love of peace and apply it. With the love of peace in a person, his life will feel calm and safe because he can control himself and his emotions without hostility (Amran et al., 2020; Lavy, 2019; Nuryanti, 2019). What we must have in us is the value of caring for the environment. As God's creatures, we must care about our surroundings. Be it humans, animals or plants. The values of Malay local wisdom include: straighten intentions and beautify nature; willing to sacrifice and willing to give in; humble; maintain good relations with neighbours (Marlina, 2020).

The findings of previous studies stated that local wisdom could shape students' character (Aryantini et al., 2018; Primayanti et al., 2019). Other research findings also state that local wisdom can be used as a learning resource and improve students' social attitudes (Aditya et al., 2019; Lidi et al., 2020; Widyanti, 2015). There is no study of the value of Malay local wisdom in learning in elementary schools. This study aims to analyze the value of Malay local wisdom in learning in elementary schools. The application of the value of local Malay wisdom is expected to prepare students to have a solid insight into their environment. With local content learning, students can learn about Malay culture and know what culture is in their environment.

\section{METHOD}

This study uses a qualitative approach and descriptive methods in its research. So, the data collected by researchers can help describe the situation in the field. With this data set, the researcher was 
able to describe the results of the observations made. The steps in this research are preparation, including drafting, selecting research sites, preparing instruments, taking care of permits; the field includes conducting research, data collection; data processing includes data reduction, data display, analysis, conclusion. Sources of research data obtained from research subjects. The subjects in this study were students, principals, and teachers of SD Negeri 67 Pekanbaru. This study determines its data sources to obtain information regarding the application or implementation of local wisdom values at SD Negeri 67 Pekanbaru. The data sources in this study were 1 principal, 7 teachers and 16 students. Researchers made observations starting from grades 1 to 6 with representatives of 6 classes. The location of this research is SD Negeri 67 Pekanbaru. The data collection methods used are interviews, observation and documentation. When making observations, researchers make observations as listed in the table below, as follows:

Table 1. Observation Guidelines

\begin{tabular}{ll}
\hline \multicolumn{1}{c}{ Indicator } & \multicolumn{1}{c}{ Sub Indicator } \\
\hline Religious Value & Pray before and after study \\
& Read the Qur'an before starting the lesson \\
& Follow Imtaq activities every Friday morning \\
& Islamic holidays \\
The Value of Mutual Cooperation & Carry out class picket \\
& Make a classroom corner \\
Value Caring for the environment & Make a garden in front of the class \\
& Gotong royong every 2 weeks on Saturday \\
& Recycle waste in the form of handicrafts \\
Tolerance Value & Introducing the holy places of other religions and how to \\
& worship them \\
& Cultural introduction every Independence Day celebration \\
Peace Love Value & Forming class device \\
& School rules about the culture of peace \\
\hline
\end{tabular}

The procedure in this study is to make initial observations, determine the topic of the problem, compile research instruments; data collection in the field; perform data analysis, make discussions and conclusions. Data collection techniques are in the form of observation, documentation, Interviews. The instruments used are observation guidelines, documentation guidelines, and interview guidelines. Data analysis used descriptive qualitative. Analysis of research data using the Miles and Huberman model, namely, data reduction, data presentation, concluding. In testing the validity of the data, the researcher uses triangulation.

\section{RESULT AND DISCUSSION}

\section{Result}

Based on the observations, it was found that the value of Malay local wisdom applied in elementary schools was religious value. They have seen when the teacher greets and asks students to pray before online learning begins. In addition to religious values, there is the value of caring for the environment that appears when researchers make observations. When he is not online, the teacher can be seen watering the garden in front of the teacher council office in his spare time. It includes the value of caring for the environment because the teacher feels that plants are living beings like us who want to live and be cared for. So there are two values of local Malay wisdom that are still applied during the pandemic, namely religious values and environmental care values. Based on the results of interviews with teachers, it was found that the value of local wisdom applied in elementary schools is the value of tolerance. It was proven when the teacher gave a lesson on the beauty of my country's diversity. The teacher explains the material in the form of short messages via WA and learning videos. That Indonesia has many different tribes, religions and cultures. Even though we have many differences, we must respect and appreciate each other between followers of different religions as fellow human beings.

Based on observations, it was found that before starting online learning, the teacher asked students to pray before starting the lesson. Furthermore, the teacher provides material in the form of videos, pictures, and notes to be understood by students and gives assignments that students must do at home as a form of online learning activities. After the teacher gives the material, the teacher closes the lesson by motivating the students and ends by saying greetings. During online learning, students do not read the Qur'an together, but the teacher asks students to read the Qur'an independently at home with parental 
guidance. In addition, the imtaq activity, which is usually carried out every Friday, was also not carried out due to the Covid-19 pandemic. It was done to reduce crowds to prevent the spread of the virus. The commemoration of Islamic holidays is also not carried out to avoid crowds. During the pandemic, there will be no class picket due to online learning. The mid-semester activity program is still implemented but is carried out online to determine student learning progress. The program in making classroom corners which are usually done, is also not implemented because parents and students are not allowed to come to school. Other student activities such as making a garden in front of the class, cooperation and recycling of the waste in the form of handicrafts also could not be carried out due to the covid-19 pandemic. The school does not want any of its teachers and students to be exposed to the virus.

Previously, the teacher introduced each religion's holy places, religious rituals, and culture through lecture and picture methods. However, since online learning, the teacher does not appear to be doing this. The teacher focuses more on learning materials and media as a tool for teachers to understand students. The introduction of the culture of each region in the commemoration of independence day was also not carried out because students did not attend school face to face, so it was not possible to conduct competitions as a form of enlivening the independence day event. During face-to-face learning, the teacher forms class sets with students to secure the class when the teacher is not in class. For example, the elected class president will carry out his duties to lead students to pray and secure the class when the class is noisy and make the learning atmosphere not conducive. The rules made and implemented by the school are also helpful in creating a culture of peace in the school. Besides that, it also makes students disciplined and has good morals with rules that must be obeyed.

Based on the results of interviews with the principal, information was obtained that reading the Qur'an every morning is the school's vision and mission so that elementary school graduates become students who love the Qur'an and can increase faith and piety to God Almighty. Imtaq activities held every Friday help educate students to have good morals (good morals), form the religious character of students so that they can understand religious teachings, and have faith and fear of God Almighty. Almighty. In order to commemorate the big day of Islam, schools carry out activities by inviting clerics to give tausiah, both to educators and to students and carry out competitions such as short verse reading competitions and call to prayer competitions. The school also has a program for making classroom corners. For classes with a good and exciting reading corner, prizes will be given in trophies and storybooks. So that in the future, students will be motivated to read diligently because they have a beautiful and comfortable reading corner. The school carries out cooperation every two weeks and is attended by all school members. This gotong-royong activity is by the school's vision and mission, namely increasing the participation of school residents to create a comfortable, clean, and healthy environment. When commemorating Indonesia's independence day, schools carry out ceremonies and hold competitions related to the cultural introduction. So that with the competition, students can get to know the culture of each region. In order to create a culture of peace between all teachers and students, schools apply rules to be able to respect and respect each other and be able to work together.

Based on the interviews with teachers, information was obtained that teachers remind students to always read prayers before and after learning ends. The teacher also motivates students by encouraging students that by reading prayers, students can receive learning quickly and limit students from deviant behaviour, so that every activity carried out in learning runs smoothly and is blessed by Allah SWT. By reading prayers can shape character and instil moral and religious values. Moreover, of course, reading prayers can make students always remember Allah in every activity they do. In addition to reading the prayer before starting the lesson, the teacher also asks students to read the Qur'an for high-grade students and read short verses for high-grade students. Al-Qur'an reading activities are carried out every Tuesday, Wednesday, and Thursday because on Monday, students carry out the flag ceremony, on Friday, students participate in imtaq, and Saturday students participate in gymnastics. This activity was carried out before the covid 19 pandemic. Since the outbreak, this activity was not carried out because learning was carried out online. Every Friday there is an imtaq activity. Imtaq implementing officers are students whom the teacher has chosen. When elected as the implementing officer of IMTAQ, of course, some students immediately accept and reject. For students who refuse to become officers, the teacher motivates them so that they do not refuse and encourages them to set an example for other students by becoming IMTAQ implementing officers. The teacher also makes a schedule so that no more students refuse to become IMTAQ implementing officers. The teacher gives an excellent explanation to the students because imtaq is also included in the character that can instil moral and religious values in students. If a student cannot appear as an officer, the only way is to find a replacement officer so that the imtaq activity can be carried out and run smoothly. However, this activity was carried out before the covid 19 pandemic. Since the outbreak, this activity was not carried out because learning was carried out online. The school also holds events, one of which is by inviting clerics to give tausiah or spiritual showers. All school members attended the event, and 
although there were different beliefs, both students and teachers still attended it as a form of respect and appreciation. This activity was carried out before the covid 19 pandemic. Since the outbreak, this activity was not carried out because learning was carried out online.

Before the pandemic, school students were face-to-face. Every day, students carry out class pickets to study comfortably because the environment is clean and neatly arranged. This class picket only applies to grades two to six; first graders do not carry out class pickets. For students who do not carry out class pickets according to the schedule, the teacher asks students to carry out pickets after learning hours are over or the next day. Some teachers give sanctions by telling them to picket for three days in a row. The school also has a program for making classroom corners in each class. Students and parents participate in making classroom corners to be completed quickly. The teacher supervises the making of the classroom corner and assists if students need it. In addition, the teacher also provides ideas in making classroom corners and motivates students to be more active in reading books because they can add knowledge and have broad insights. The teacher also invites students to make a garden in front of the class. Plants planted in front of the class are ornamental plants and medicinal plants. A garden in front of the class can be used as a medium of learning for students about the environment around the class. In addition, the presence of a garden in front of the class makes students comfortable, calm and more enthusiastic in learning because they can know the parts of plants directly.

Every Saturday, the school holds gotong royong. Gotong royong is followed by all school members. All students are required to bring tools that will be used during cooperation. For students who do not bring tools, the teacher asks students to do what they can do using the tools in the classroom, pick up trash and water the plants. The teacher also warned students so that in the future, if there are cooperation activities, students do not forget to bring the equipment needed. The teacher moves the students to make handicrafts either by recycling waste or making other handicrafts. Some students make flower pots and fences for the reading corner from used tissue boxes from the newspaper, photo frames made of seashells, collages of dried leaves and seeds and beads. Some students make batik, make sculptures from soap and make statues out of clay. Primary schools in Pekanbaru come from adherents of different religions. The teacher tells the students the rituals and places of worship of each religion. The teacher tells the students that each religion has its place of worship and has religious holidays. The teacher informs the students using the lecture method (source of the handbook), using media images, videos, and if necessary, inviting students to places of worship according to their religion and digging up information from students of different religions. Some teachers give students assignments in the form of clippings. The teacher also introduces the culture and traditions of each religious tribe in learning by introducing regional specialities, traditional clothing, and regional languages. The teacher also uses the lecture method sourced from the handbook, uses image media, uses audio media (regional songs) and sees the video shown by the teacher..

Each class has a class device, one of which is the class president, who helps secure the class so that it does not get noisy if someone makes a fuss - the selection of this class device by voting. Before voting, the teacher consults with the students, who will be nominated as class apparatus. The result of the most votes will be the class apparatus. The class apparatus consists of a chairperson, deputy, secretary and treasurer. All of that is inseparable from the teacher's goal to create a peaceful classroom atmosphere, especially in learning. Teachers can create a different classroom atmosphere, increase interaction by provoking students' ideas, using technology, humorous nature, and giving equal attention to children. In addition, by applying a rule-abiding/disciplined attitude in the classroom, students are asked to foster cooperation between students and mutual respect. Some teachers provide interludes in the form of stories in learning to stay excited and make the atmosphere as comfortable as possible. If there is material about knowing the environment, the teacher invites students to study outside the classroom. Based on interviews with students, information was obtained that before starting learning and after learning ended, all students read prayers. As the teachings of Islam, every start / start an activity start by praying to be blessed by Allah. By praying, we are also always in the protection of Allah, getting easy in remembering lessons. During face-toface learning, praying is led by the class leader, but in online learning, students are praying individually in their respective homes. Before the outbreak, every specific day, all students read the Qur'an before starting learning. Except for non-Muslim students, they were told to be quiet by the teacher and not invite other friends to talk. Sometimes there are still students who are tempted to talk to their friends. Those who are not tempted to talk tell their friends to be quiet with sign language. Some rebuke directly not to interfere and, after that, continue reading.

Every Friday morning, an imtaq activity is held. All students participated in this activity. IMTAQ implementing officers are students whom the teacher has selected before the IMTAQ is implemented. The students were selected as short verse reader officers, protocol/presenters, Salawat readers, and nasyid. Each student will get a turn to become an imtaq officer because the teacher has made a schedule for the imtaq officer. This activity is always held every Friday morning before the pandemic. However, after the 
pandemic, the imtaq activity was cancelled due to online learning. During the commemoration of Islamic holidays, the school held an event. All students attended the event. In addition to tausiah by inviting clerics to school, religious competitions were held, such as the call to prayer and tambourine competitions. All students are enthusiastic about the competition. During face-to-face learning, each student carries out a class picket. Students carry out pickets according to their schedules. Every day there are four to five people who carry out class pickets. Picket students must sweep the classroom and clean the blackboard. Students who do not carry out class pickets must picket after class hours are over or after school. Since online learning, the class picket is not abolished. Every class in Pekanbaru elementary school has a corner. In the corner of the classroom, there are reading books, decorations and handicrafts made by students. The class corner is very beneficial for every student. In addition to increasing students' interest in reading, it can also increase knowledge and broaden horizons. Students can also use their free time to read. With a classroom corner, students feel they have a personal library in the classroom.

Every class in Pekanbaru elementary school has a garden in front of the class. Teachers and students planted the plants. Every day students water the plants so they can thrive and not die. In addition, students also carry out routine activities every two weeks, namely cooperation. All students work together. When working together, students bring the tools they need. However, since the pandemic, students and teachers have never carried out gotong-royong together again. In addition to having achievements in the academic field, Pekanbaru elementary school students are creative students. Students can make handicrafts from waste, which is known as waste recycling. Students have produced many crafts. Among them are making flowers from used bottles, making flower pots, piggy banks, pencil cases, baskets, wallets, and tissue boxes. They display the handicrafts in the corner of the classroom to enjoy the beauty of the results of their efforts. In elementary school, not all students are Muslim. They come from adherents of different religions. Different beliefs, of course, the way of worship is also different. However, they respect each other and do not discriminate. When friends from different religions carry out their worship, other students respect and do not make noise to focus on worshipping their God. In addition, some of them come from different tribes. Of course, it has a different culture too. However, they still respect each other and respect their friends who are of different ethnicity and culture. Each class has a class apparatus consisting of a chairperson, deputy, secretary and treasurer. Each class device has its responsibilities. The class leader is obliged to lead the prayer and prepare the line before entering class. The vice-chairman is obliged to help the class president if he is not there. The treasurer is in charge of collecting class cash which will later be used for class needs. The secretary is in charge of taking notes on the blackboard ordered by the teacher. Class devices are also tasked with securing the class if something makes the class noisy. Tell them to be quiet so that the class atmosphere is not noisy and they can study quietly. Reprimand them, of course, in a polite way and give them understanding.

\section{Discussion}

Pekanbaru elementary school has implemented the value of local wisdom in school and also in learning. The values of local wisdom of the Indonesian people, including religious values, cooperation values, environmental care values, peace-loving values, and tolerance values (Aryantini et al., 2018; Primayanti et al., 2019). The local wisdom of the Indonesian people is also the same as the value of Malay local wisdom, especially in the Riau area. This value of local wisdom is applied in schools, especially in elementary schools. In each of these values of wisdom, many things can be observed as a form of implementation in the value of local wisdom. The noble values of local wisdom are the love of God, responsibility, discipline, independence, and honesty (Aditya et al., 2019; Khoeriyah \& Mawardi, 2018; Widyanti, 2015). The learning implemented currently refers to the 2013 curriculum. The essence of the 2013 curriculum is to increase students' knowledge and provide students with skills and nobility according to the nation's personality (Divayana et al., 2016; Fitri et al., 2017; Suyanto, 2018). The learning system in the 2013 curriculum is designed by connecting one subject with other subjects in the form of themes (Astuti \& Darsinah, 2018; Kurniasari, 2017). Learning activities are carried out using a scientific approach to support the achievement of students' cognitive, affective, and psychomotor competencies (Cerit, 2013; Maharani, 2015). The 2013 curriculum motivates students to participate actively in order to be able to develop students' creativity and independence (Kurniaman \& Noviana, 2017; Maryani \& Martaningsih, 2017).

Implementing religious values includes prayer or worship activities at school, commemorating religious holidays, gratitude and sharing programs, and religious-based extracurricular programs. The implementation of the value of tolerance is to introduce various holy places of other religions and how to worship them, programs to clean places of worship in the surrounding environment (Arsanti, 2018; Rosikum, 2018; Silkyanti, 2019). The implementation of the value of gotong royong consists of mutual assistance in helping clean public facilities, mid-semester activity programs, and creating a classroom 
creation corner (Ningsih, 2018; Sujatmiko et al., 2019). Implementing peace-loving values includes forming class deliberation boards, peace-loving days, drafting peace resolutions, and school regulations on a culture of peace (Aryantini et al., 2018; Primayanti et al., 2019). Implementation of the value of caring for the environment, namely the annual 1000 plant movement program, establishing a school environmental stewardship board, and studying the introduction of the natural environment. The hope in the future from the school is that after the covid pandemic ends, all the values of wisdom can be carried out optimally. Suggestions from researchers for related parties, namely, teachers, want to learn more about the values of local wisdom that can be applied in learning to be implemented optimally. Teachers should be more enthusiastic in cultivating the value of local wisdom so that students can also be excited to follow and apply it (Lidi et al., 2020; Rachmadyanti, 2017). In addition, schools must also have this local wisdom program aimed at teachers and students to be carried out optimally. Each activity carried out must have a plan or design and have a report as a school archive.

\section{CONCLUSION}

The value of local Malay wisdom is significant to be applied in schools, especially in learning. The value of Malay local wisdom is significant to be applied in schools so that students have good morals, character, and manners to behave and behave according to the culture in their environment.

\section{REFERENCES}

Aditya Dharma, I. M. (2019). Pengembangan Buku Cerita Anak Bergambar Dengan Insersi Budaya Lokal Bali Terhadap Minat Baca Dan Sikap Siswa Kelas V Sd Kurikulum 2013. Journal for Lesson and Learning Studies, 2(1), 53-63. https://doi.org/10.23887/jlls.v2i1.17321.

Aditya, I. K. D., Sumantri, M., \& Astawan, I. G. (2019). Pengaruh Model Pembelajaran Learning Cycle (5e) Berbasis Kearifan Lokal Terhadap Sikap Disiplin Belajar Dan Hasil Belajar Ipa Siswa Kelas Iv Sd Gugus V Kecamatan Sukasada. Jurnal Pendidikan Multikultural Indonesia, 2(1). https://doi.org/10.23887/jpmu.v2i1.20792.

Aggari, M. I., Diño, M. J. S., \& Orte, C. J. S. (2020). Leaders shaping leadership: Knowledge, professional values and competency as prognosticators of career growth and development among nurses. Enfermería Clínica, 30(1). https://doi.org/10.1016/j.enfcli.2019.09.020.

Alba, A. P., Akbar, S., \& Nurchasanah, N. (2019). Bahan Ajar Tema Daerah Tempat Tinggalku Berbasis Kearifan Lokal. Jurnal Pendidikan: Teori, Penelitian, Dan Pengembangan, 4(4), 421-426. https://doi.org/10.17977/jptpp.v4i4.12228.

Amran, A., Jasin, I., Perkasa, M., Satriawan, M., Irwansyah, M., \& Erwanto, D. (2020). Implementation of education for sustainable development to enhance Indonesian golden generation character. Journal of Physics: Conference Series, 1521(4), 1-5. https://doi.org/10.1088/1742-6596/1521/4/042102.

Aragonés-González, M., Rosser-Limiñana, A., \& Gil-González, D. (2020). Coeducation and gender equality in education systems: A scoping review. Children and Youth Services Review, 111. https://doi.org/10.1016/j.childyouth.2020.104837.

Arsanti, M. (2018). Pengembangan bahan ajar mata kuliah penulisan kreatif bermuatan nilai-nilai pendidikan karakter religius bagi mahasiswa prodi PBSI, FKIP. Unissula. Kredo: Jurnal Ilmiah Bahasa Dan Sastra, 1(2), 69-88. https://doi.org/https://doi.org/10.24176/kredo.v1i2.2107.

Aryantini, Agung, \& Dantes. (2018). Kontribusi Implementasi Manajemen Sekolah Berbasis Nilai-Nilai Kearifan Lokal Tri Hita Karana, Kepemimpinan Pelayan Kepala Sekolah, Budaya Sekolah dan Kepuasan Kerja Terhadap Kinerja Guru di SMP Negeri Kecamatan Sukasada Kabupaten Buleleng. Jurnal Administrasi Pendidikan Indonesia, 9(2), 99-110. https://doi.org/10.23887/japi.v9i2.2757.

Astuti, S. I., \& Darsinah, D. (2018). Penilaian Autentik Berbasis Kurikulum 2013 di SD Negeri Mangkubumen Kidul No. 16 Surakarta. Manajemen Pendidikan, 13(2), 165-174. https://doi.org/10.23917/jmp.v13i2.7484.

Barni, D., Danioni, F., \& Benevene, P. (2019). Teachers' self-efficacy: The role of personal values and motivations for teaching. Frontiers in Psychology, 10(JULY), 1-7. https: //doi.org/10.3389/fpsyg.2019.01645.

Berggren, N., \& Nilsson, T. (2016). Tolerance in the United States: Does economic freedom transform racial, religious, political and sexual attitudes? European Journal of Political Economy, 45. https://doi.org/10.1016/j.ejpoleco.2016.06.001.

Brookhart, S. M., Guskey, T. R., Bowers, A. J., McMillan, J. H., Smith, J. K., Smith, L. F., Stevens, M. T., \& Welsh, M. E. (2016). A Century of Grading Research: Meaning and Value in the Most Common Educational Measure. Review of Educational Research, 84(4). https://doi.org/10.3102/0034654316672069. 
Budiwibowo, S. (2016). Membangun Pendidikan Karakter Generasi Muda Melalui Budaya Kearifan Lokal Di Era Global. Premiere Educandum: Jurnal Pendidikan Dasar Dan Pembelajaran, 3(01), 39-49. https://doi.org/10.25273/pe.v3i01.57.

Cerit, Y. (2013). Relationship between Teachers' Self-Efficacy Beliefs and Their Willingness to Implement Curriculum Reform. International Journal of Educational Reform, 22(3), 252-270. https://doi.org/10.1177/105678791302200304.

DiMaggio, P., Sotoudeh, R., Goldberg, A., \& Shepherd, H. (2018). Culture out of attitudes: Relationality, population heterogeneity and attitudes toward science and religion in the U.S. Poetics, 68(October), 31-51. https://doi.org/10.1016/j.poetic.2017.11.001.

Divayana, D. G. H., Suyasa, P. W. A., \& Sugihartini, N. (2016). Pengembangan Media Pembelajaran Berbasis Web Untuk Matakuliah Kurikulum dan Pengajaran di Jurusan Pendidikan Teknik Informatika Universitas Pendidikan Ganesha. Jurnal Nasional Pendidikan Teknik Informatika (JANAPATI), 5(3), 149. https://doi.org/10.23887/janapati.v5i3.9922.

Faizah, U., Zuchdi, D., \& Alsamiri, Y. (2019). An authentic assessment model to assess kindergarten students' character. Research and Evaluation in Education, 5(2), 103-119. https://doi.org/10.21831/reid.v5i2.24588.

Fauyan, M. (2019). Developing Interactive Multimedia Through Ispring on Indonesian Language Learning with The Insights of Islamic Values in Madrasah Ibtidaiyah. Al Ibtida: Jurnal Pendidikan Guru MI, 6(2), 177. https://doi.org/10.24235/al.ibtida.snj.v6i2.4173.

Fitri, Saparahayuningsih, \& Agustriana. (2017). Perencanaan Pembelajaran Kurikulum 2013 Pendidikan Anak Usia Dini. Jurnal Ilmiah Potensia, 2(1). https://doi.org/10.33369/jip.2.1.1-13.

Hamdi, S., Suganda, I. A., \& Hayati, N. (2018). Developing higher-order thinking skill (HOTS) test instrument using Lombok local cultures as contexts for junior secondary school mathematics. Research and Evaluation in Education, 4(2), 126-135. https://doi.org/10.21831/reid.v4i2.22089.

Juarascio, A. S., Felton, J. W., Borges, A. M., Manasse, S. M., \& Murray, H. B. (2016). An investigation of negative affect, reactivity, and distress tolerance as predictors of disordered eating attitudes across adolescence. Journal of Adolescence, 49. https://doi.org/10.1016/j.adolescence.2016.02.005.

Khaerunnnisa, E., \& Pamungkas, A. S. (2019). Pengembangan Instrumen Kecakapan Matematis Dalam Konteks Kearifan Lokal Budaya Banten Pada Materi Bangun Ruang Sisi Datar. Kreano Jurnal Matematika Kreatif-Inovatif, 9(1). https://doi.org/10.15294/kreano.v9i1.11210.

Khoeriyah, N., \& Mawardi, M. (2018). Penerapan Desain Pembelajaran Tematik Integratif Alternatif Berbasis Kearifan Lokal untuk Meningkatkan Hasil dan Kebermaknaan Belajar. Mimbar Sekolah Dasar, 5(2), 63. https://doi.org/10.17509/mimbar-sd.v5i2.11444.

Kurniaman, O., \& Noviana, E. (2017). Penerapan Kurikulum 2013 Dalam Meningkatkan Keterampilan, Sikap, Dan Pengetahuan. Primary: Jurnal Pendidikan Guru Sekolah Dasar, 6(2), 389. https: //doi.org/10.33578/jpfkip.v6i2.4520.

Kurniasari, F. (2017). Implementasi Pendekatan Saintifik Pada Penugasan Aktivitas Di Buku Teks Bahasa Indonesia Kelas VII SMP Berdasarkan Kurikulum 2013. Jurnal Pendidikan Edutama, 4(1), 9-26. https://doi.org/10.30734/jpe.v4i1.44.

Lavy, S. (2019). A Review of Character Strengths Interventions in Twenty-First-Century Schools: their Importance and How they can be Fostered. Applied Research Quality Life, 1(1). https://doi.org/10.1007/s11482-018-9700-6.

Lestariningsih, N., \& Suardiman, S. P. (2017). Pengembangan Bahan Ajar Tematik-Integratif Berbasis Kearifan Lokal Untuk Meningkatkan Karakter Peduli Dan Tanggung Jawab. Jurnal Pendidikan Karakter, 7(1). https://doi.org/10.21831/jpk.v7i1.15503.

Lidi, M. W., Ningsih, \& Dhiki, Y. Y. (2020). Identifikasi Potensi Kearifan Lokal Masyarakat Golewa Kabupaten Ngada sebagai Upaya Pengembangan di Bidang Pendidikan. OPTIKA: Jurnal Pendidikan Fisika, 4(1), 21-29. https://doi.org/10.37478/optika.v4i1.332.

Lyon, M. A. (2021). Heroes, villains, or something in between? How "Right to Work" policies affect teachers, students, and education policymaking. Economics of Education Review, 82. https://doi.org/10.1016/j.econedurev.2021.102105.

Maharani, Y. S. (2015). Efektivitas Multimedia Pembelajaran Interaktif Berbasis Kurikulum 2013. Indonesian Journal of Curriculum and Educational Technology Studies, 3(1), 31-40. https://doi.org/10.15294/ijcets.v3i1.8683.

Marhayani, D. A. (2016). Development of Character Education Based on Local Wisdom in Indegenous People Tengahan Sedangagung. JETL (Journal of Education, Teaching and Learning), 1(2), 66. https://doi.org/10.26737/jetl.v1i2.40.

Marlina. (2020). Nilai Kearifan Lokal dalam Tunjuk Ajar Melayu Karya Tenas Effendi. Balai Bahasa Riau, $28(2)$. 
Maryani, I., \& Martaningsih, S. T. (2017). Persepsi Guru Sekolah Dasar Terhadap Sistem Penilaian Pada Kurikulum 2013. Scholaria: Jurnal Pendidikan Dan Kebudayaan, 7(2), 153-164. https://doi.org/10.24246/j.scholaria.2017.v7.i2.p153-164.

Maudsley, G., \& Taylor, D. (2020). Analysing synthesis of evidence in a systematic review in health professions education: observations on struggling beyond Kirkpatrick. Medical Education Online, 25(1). https://doi.org/10.1080/10872981.2020.1731278.

Ningsih, Y. (2018). Penilaian Sikap Sosial Pada Anak Berkebutuhan Khusus Di Slb Negeri 2 Yogyakarta. Jurnal Bimbingan Dan Konseling Islam, 08(02), 208-215. https: //doi.org/10.29080\%2Fjbki.v8i2.85.

Nurafni, A., Pujiastuti, H., \& Mutaqin, A. (2020). Pengembangan Bahan Ajar Trigonometri Berbasis Kearifan Lokal. Journal of Medives: Journal of Mathematics Education IKIP Veteran Semarang, 4(1), 71. https://doi.org/10.31331/medivesveteran.v4i1.978.

Nuryanti, A. D. (2019). Character Education and Creativity of Ideas in the Speech Acts of the Main Character of the Fantasy Text Based on Local Wisdom. St International Conference on Language, Literature, and Arts Education, 146. https://doi.org/10.2991/assehr.k.200804.047.

Primayanti, P. E., Suarjana, I. M., \& Astawan, I. G. (2019). Pengaruh Model Pbl Bermuatan Kearifan Lokal terhadap Sikap Sosial dan Kemampuan Berpikir Kritis Matematika Siswa Kelas V di Gugus V Kecamatan Sukasada. Thinking Skills and Creativity Journal, 1(2), 86. https://doi.org/10.23887/tscj.v1i2.20417.

Rachmadyanti, P. (2017). Penguatan Pendidikan Karakter Bagi Siswa Sekolah Dasar Melalui Kearifan Lokal. Jurnal Pendidikan Sekolah Dasar, 3(2), 201-214. https://doi.org/10.30870/jpsd.v3i2.2140

Rosikum, R. (2018). Pola Pendidikan Karakter Religius pada Anak melalui Peran Keluarga. Jurnal Kependidikan, 6(2). https://doi.org/10.24090/jk.v6i2.1910.

Saputro, F. E. (2020). The Role Of Islamic Religious Education Teachers In Actualizing Tolerance Attitudes To Students. AL-ISHLAH: Jurnal Pendidikan, 12(2), 336-347. https://doi.org/10.35445/alishlah.v12i2.214.

Silkyanti, F. (2019). Analisis Peran Budaya Sekolah yang Religius dalam Pembentukan Karakter Siswa. Indonesian Values and Character Educational Journal, 2(1), 36-42. https://doi.org/10.23887/ivcej.v2i1.17941.

Sudarmiani, S. (2013). Membangun Karakter Anak Dengan Budaya Kearifan Lokal Dalam Proses Pembelajaran Di Sekolah. EQUILIBRIUM : Jurnal Ilmiah Ekonomi Dan Pembelajarannya, 1(1), 54-72. https://doi.org/10.25273/equilibrium.v1i1.556.

Sujatmiko, I. N., Arifin, I., \& Sunandar, A. (2019). Penguatan Pendidikan Karakter di SD. Jurnal Pendidikan, 4(8), 200-215. https://doi.org/10.24090/jk.v5i2.2109.

Sutarto, D. (2016). Kearifan Budaya Lokal Dalam Pengutan Tradisi Malemang Di Tengah Masyarakat Modernisasi Di Sungai Keruh Musi Banyuasin Sumatera Selatan. Jurnal Dimensi, 5(3), 2-6. https://doi.org/10.33373/dms.v5i3.54.

Suyanto, S. (2018). The Implementation Of The Scientific Approach Through $5 \mathrm{~ms}$ Of The Revised Curriculum 2013 In Indonesia. Cakrawala Pendidikan, 37(1), 22-29. https://doi.org/10.21831/cp.v37i1.18719.

Tambak, S., \& Sukenti, D. (2017). Implementasi Budaya Melayu dalam Kurikulum Pendidikan Madrasah Ibtidaiyah di Riau. MIQOT Jurnal Ilmu-Ilmu Keislaman, 41(2). https://doi.org/10.30821/miqot.v41i2.409.

Utomo, E. P. (2018). Internalisasi Nilai Karakter Gotong Royong dalam Pembelajaran IPS untuk Membangun Modal Sosial Peserta Didik. Jurnal Teori Dan Praksis Pembelajaran, 3(2), 95-102.

Van Nuland, S., Mandzuk, D., Tucker Petrick, K., \& Cooper, T. (2020). COVID-19 and its effects on teacher education in Ontario: a complex adaptive systems perspective. Journal of Education for Teaching, 46(4), 442-451. https://doi.org/10.1080/02607476.2020.1803050

Wati, E. (2019). Karakteristik Budaya Melayu dalam Kumpulan Cerita Yong Dolah Versi Abdul Razak. Jurnal Tuah Pendidikan Dan Pengajaran Bahasa, 1(1). https://doi.org/10.31258/jtuah.1.1.p.51-59.

Widyanti, T. (2015). Penerapan Nilai-Nilai Kearifan Lokal Dalam Budaya Masyarakat Kampung Adat Cireundeu Sebagai Sumber Pembelajaran IPS. Jurnal Pendidikan Ilmu Sosial, 24(2). https://doi.org/10.17509/jpis.v24i2.1452.

Wijaya, A. P., Mahayukti, G. A., Gita, I. N., \& Parwati, N. N. (2019). Pengaruh strategi Relating, Experiencing, Applying, Cooperating, Transfering berorientasi kearifan lokal terhadap pemecahan masalah dan karakter. Pythagoras: Jurnal Pendidikan Matematika, 14(2), 178-187. https://doi.org/10.21831/pg.v14i2.25881. 